\title{
Genotype-Site Interactions in Growth, Physiological and Biochemical Parameters in Clones of Dalbergia Sissoo Roxb.
}

\author{
By R. S. RAWAT*) and S. NAUTIYAL \\ Plant Physiology Discipline, Botany Division, Forest Research Institute, Dehradun - 248006 (UA) India
}

(Received $4^{\text {th }}$ January 2006)

\begin{abstract}
Summary
A plantation trial of six selected clones of Dalbergia sissoo Roxb. laid out in randomized block design at four sites in northern India during July, 1996 was evaluated for growth, physiological and biochemical parameters. Genotype-site interactions were significant for collar diameter increment, photosynthetic rate, transpiration rate, stomatal conductance, photosynthetic pigments, total soluble protein, total soluble sugar and starch content at 5 per cent level of significance. The variability estimates for these characters also indicated strong genetic control than the environment. However, stomatal conductance amongst these clones exhibited strong influence of environment that was non-additive in nature.
\end{abstract}

Key words: Dalbergia sissoo, clone, variability, heritability, genetic gain.

\section{Introduction}

Dalbergia sissoo Roxb., classified as one of the four primary timbers of India, has been planted in many tropical countries for timber, fuelwood, fodder, shade and stabilization of eroding landscape. Poor stem form, i.e. generally a crooked and forked bole is its stumbling block which deteriorates its timber quality. However, a great variety of stem forms exist in its natural distribution zone, which indicate possibility of improvement

*) Present Address of the communicating author: Dr. S. RAWAT. Research Officer. Biodiversity \& Climate Change Division. Indian Council of Forestry Research and Education (HQs.). Dehradun - 248009 (UK) INDIA. Fax No. 91-0177-2626779. E-mail address: rsbrawat@yahoo.co.in through selection and multiplication. The species can be multiplied clonally and thus true nature of selections can be maintained in plantations. However, the growth performance and adaptability of clones vary from one place to another due to varying abiotic factors. This aspect of clonal stability of these clones has been analysed in the present study through genotype-site interactions by the study of growth, physiological and biochemical parameters at different sites. Earlier studies of VIDAKOVIC and SIDDIQUI (1968), VIDAKOVIC and AHSAN (1970), REHMAN and HUSSAIN (1986) in this species relate to heritability of height and collar diameter.

\section{Material and Method}

A range wide selection of plus trees of Dalbergia sissoo in its distribution zone in India was carried out and vegetative planting materials (root suckers) collected and multiplied at vegetative multiplication garden at FRI, Dehradun. Six promising clones amongst these (Table 1) were further multiplied vegetatively by taking $3-4 \mathrm{~cm}$ long fresh softwood cuttings with at least 1-2 leaves from the coppice shoots, dipped in $1000 \mathrm{ppm}$ IBA, and rooted in vermiculite under mist chamber (70-80\% rooting success). After rooting, cuttings were transferred to polythene bags containing a mixture of soil, sand and FYM mixture. After a year in the nursery these clonal plants were planted in a Randomized Block Design with three blocks in different climatic zones of northern India during July, 1996. Each block consisted of nine ramets at a spacing of $6 \mathrm{~m} \times 6 \mathrm{~m}$ (Table 2 ).

Table 1. - Geographical details of the Dalbergia sissoo clones.

\begin{tabular}{|c|c|c|c|c|c|c|}
\hline $\begin{array}{c}\text { Clon } \\
\mathrm{e}\end{array}$ & $\begin{array}{c}\text { Stat } \\
\mathrm{e}\end{array}$ & Circle & Division & Range & Beat & $\begin{array}{c}\text { Compartmen } \\
t\end{array}$ \\
\hline C019 & UA & Haridwar & Haridwar & Khanpur & $\begin{array}{c}\text { Shahmansoorpu } \\
\mathrm{r}\end{array}$ & -- \\
\hline C034 & UP & Gonda & North Gonda & Tulsipur & Bhainsasur & 2 \\
\hline C066 & HR & $\begin{array}{l}\text { Yamuna } \\
\text { Nagar }\end{array}$ & $\begin{array}{l}\text { Yamuna } \\
\text { Nagar }\end{array}$ & Chhichrauli & -- & -- \\
\hline $\mathrm{C} 083$ & RJ & $\begin{array}{c}\text { Hanumangar } \\
\mathrm{h}\end{array}$ & $\begin{array}{c}\text { Hanumangar } \\
\mathrm{h}\end{array}$ & $\begin{array}{c}\text { Hanumangar } \\
\mathrm{h}\end{array}$ & -- & 12 A Kola \\
\hline $\mathrm{C} 087$ & RJ & $\begin{array}{c}\text { Hanumangar } \\
\mathrm{h}\end{array}$ & $\begin{array}{c}\text { Hanumangar } \\
\mathrm{h}\end{array}$ & $\begin{array}{c}\text { Hanumangar } \\
\mathrm{h}\end{array}$ & -- & 12 A Kola \\
\hline C192 & UP & Gonda & North Gonda & Tulsipur & Hasnapur & 2 \\
\hline
\end{tabular}


Table 2. - Details of the experimental sites.

\begin{tabular}{|l|c|c|c|c|}
\hline \multicolumn{1}{|c|}{ Site Parameters } & $\begin{array}{c}\text { Lachhiwala, } \\
\text { Dehradun } \\
\text { (UA) }\end{array}$ & $\begin{array}{c}\text { Lalkuwan, } \\
\text { Haldwani } \\
\text { (UA) }\end{array}$ & $\begin{array}{c}\text { Bithmera, } \\
\text { Hisar (HR) }\end{array}$ & $\begin{array}{c}\text { Pandhori } \\
\text { Mindo Mind, } \\
\text { Hoshiyarpur } \\
\text { (PB) }\end{array}$ \\
\hline A. Geographic Details: & $30^{0} 11^{\mathrm{I}} 60 \mathrm{~N}$ & $29^{0} 10^{\mathrm{I}} 00 \mathrm{~N}$ & $29^{0} 33^{\mathrm{I}} 00 \mathrm{~N}$ & $31^{0} 31^{\mathrm{I}} 60 \mathrm{~N}$ \\
\hline 1. Latitude & $78^{0} 07^{\mathrm{I}} 00 \mathrm{E}$ & $79^{0} 31^{\mathrm{I}} 00 \mathrm{E}$ & $75^{0} 55^{\mathrm{I}} 00 \mathrm{E}$ & $75^{0} 54^{\mathrm{I}} 60 \mathrm{~N}$ \\
\hline 2. Longitude & 512 & 423 & 216 & 290 \\
\hline 3. Altitude (m) & 8.00 & 6.42 & 7.40 & 6.45 \\
\hline B. Soil Parameters: & 0.26 & 0.29 & 0.24 & 0.09 \\
\hline 1. pH & 0.27 & 0.46 & 0.49 & 0.10 \\
\hline 2. E.C. (mS) & 137.90 & 188.20 & 150.50 & 125.40 \\
\hline 3. Organic Carbon (\%) & 48.40 & 63.80 & 70.60 & 73.20 \\
\hline $\begin{array}{l}\text { 4. Available Nitrogen } \\
\text { (kg /ha) }\end{array}$ & 22.40 & 78.40 & 156.80 & 23.50 \\
\hline $\begin{array}{l}\text { 5. Available Phosphorus } \\
\text { (kg /ha) }\end{array}$ & 170.00 & 230.00 & 320.00 & 120.00 \\
\hline $\begin{array}{l}\text { 6. Available Potassium } \\
\text { (kg /ha) }\end{array}$ & 122.00 & 174.00 & 185.00 & 195.00 \\
\hline 7. Calcium (ppm) & & & \\
\hline 8. Magnesium (ppm) & & & & \\
\hline
\end{tabular}

Growth (height and collar diameter), physiological (photosynthetic rate, transpiration rate and stomatal conductance) and biochemical parameters (chlorophyll \& carotenoids, total soluble protein, sugar and starch contents) were recorded at quarterly intervals for two years (November 1998 to March 2001). Photosynthetic rate, transpiration rate and stomatal conductance were measured by Portable Photosynthesis System/Infra Red Gas Analyzer between 10.00 to 11.00 AM by selecting four fully expanded sunlit leaves on four ramets per replication per clone, while their leaf area was measured by Leaf Area Meter. Leaf samples were analysed for chlorophyll and carotenoid content after HoLM (1954), total soluble protein content after LowRY et al. (1951) and total sugars after DuBois et al. (1956).

The data recorded was subjected to analysis of variance to quantify the variation among clones and sites. Genotypic, phenotypic and environmental variances; phenotypic coefficient of variation and genotypic coefficient of variation was calculated using the formulae given by BuRTon and DEvANe (1953) whereas environmental coefficient of variation was calculated using the formula given by BURTON (1952). Broad sense heritability and genetic gain were calculated using the formulae given by JoHNSON et al. (1955).

\section{Results}

Analysis of variance showed significant genotype-site interaction for collar diameter increment, photosynthetic rate, transpiration rate, stomatal conductance, photosynthetic pigments, total soluble protein, total soluble sugar and starch content in studied clones of Dalbergia sissoo at 5 per cent level of significance that was nonsignificant for height increment. Individual clonal variation with respect to growth, physiological and biochemical parameters are given in Figure 1. On the basis of observations recorded for growth, physiological and biochemical parameters; clones C192 \& C066 at Lachhiwala (Dehradun), clones C034 \& C192 at Lalkuwan (Haldwani), clones C192 \& C034 at Bithmera (Hisar) and clones C066 \& C192 at Pandhori Mindo Mind (Hoshiyarpur) were performing better. Whereas, clone C192 performing better at all the sites.

Partition of total variances in to genotypic, phenotypic, and environmental variances revealed that maximum variances were recorded at phenotypic level followed by genotypic and environmental levels for growth, physiological and biochemical parameters for all clones at all sites (Tables 3 and 4). However, growth parameters of clones at Lachhiwala (Dehradun) showed more variances at the environmental level than the genetic level. Genotypic coefficient of variation in growth, physiological and biochemical parameters of clones was in vicinity of the phenotypic coefficient of variation. Environmental coefficient of variation was much less than the genotypic and phenotypic coefficient of variation at all sites. Among the growth parameters, collar diameter increment had more variance and coefficient of variability at genotypic level than the environmental level at Lalkuwan (Haldwani) and Bithmera (Hisar). But height increment showed more variance and coefficient of variability at environmental level than the genotypic level at Lachhiwala (Dehradun) and Pandhori Mindo Mind (Hoshiyarpur). Photosynthetic rate and transpiration of clones had almost similar variances at genotypic and phenotypic level, which is also supported by coefficient of variations at genotypic and phenotypic level at all sites. Biochemical parameters of the clones also had the almost similar variances and coefficient of variability at genotypic and phenotypic levels at all sites.

Estimates of heritability (broad sense) and genetic gain for different parameters recorded very high heritability, which was in the ranges of 98.13 to 99.69 per 




1



3



5



7



2



4



6



8

Figure 1. - Individual clone variation with respect to growth (1-2), physiological (3-5) and biochemical (6-12) parameters at four sites. 


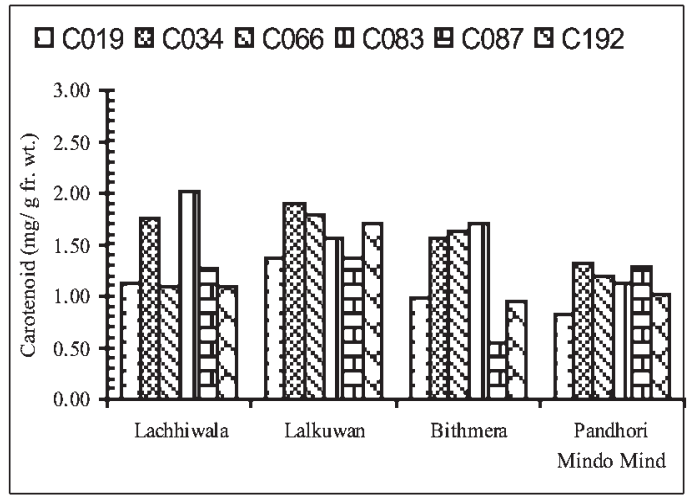

9



11



10



12

Figure 1. - Continued.

Table 3. - Estimates of phenotypic, genotypic and environmental variance components for different parameters at different sites.

\begin{tabular}{|c|c|c|c|c|c|c|c|c|c|c|c|c|}
\hline \multirow{3}{*}{ Parameters } & \multirow{2}{*}{\multicolumn{3}{|c|}{$\begin{array}{c}\begin{array}{c}\text { Lachhiwala, Dehradun } \\
\text { (UA) }\end{array} \\
\text { Variance } \\
\end{array}$}} & \multirow{2}{*}{\multicolumn{3}{|c|}{$\begin{array}{c}\begin{array}{c}\text { Lalkuwan, Haldwani } \\
\text { (UA) }\end{array} \\
\text { Variance }\end{array}$}} & \multirow{2}{*}{\multicolumn{3}{|c|}{ Bithmera, Hisar （HR) }} & \multicolumn{3}{|c|}{$\begin{array}{l}\text { Pandhori Mindo Mind, } \\
\text { Hoshiyarpur (PB) }\end{array}$} \\
\hline & & & & & & & & & & & Variance & \\
\hline & $\mathrm{Vp}$ & $\mathrm{Vg}$ & $\mathrm{Ve}$ & $\mathrm{Vp}$ & $\mathrm{Vg}$ & $\mathrm{Ve}$ & $\mathrm{Vp}$ & $\mathrm{Vg}$ & $\mathrm{Ve}$ & $\mathrm{Vp}$ & $\mathrm{Vg}$ & $\mathrm{Ve}$ \\
\hline Height Increment (m) & 0.12 & 0.04 & 0.08 & 0.32 & 0.29 & 0.03 & 0.08 & 0.06 & 0.02 & 0.17 & 0.10 & 0.07 \\
\hline Collar Diameter Increment $(\mathrm{cm})$ & 0.39 & 0.16 & 0.23 & 1.04 & 0.77 & 0.27 & 1.08 & 0.83 & 0.25 & 1.38 & 0.53 & 0.85 \\
\hline $\begin{array}{l}\text { Photosynthetic Rate } \\
\left(\mu \mathrm{mol} / \mathrm{m}^{2} / \mathrm{s}\right)\end{array}$ & 3.17 & 3.14 & 0.03 & 2.39 & 2.37 & 0.02 & 2.96 & 2.86 & 0.10 & 1.68 & 1.67 & 0.01 \\
\hline $\begin{array}{l}\text { Transpiration Rate } \\
\left(\mathrm{mmol} / \mathrm{m}^{2} / \mathrm{s}\right)\end{array}$ & 1.04 & 1.03 & 0.01 & 0.684 & 0.68 & 0.004 & 0.98 & 0.97 & 0.01 & 0.515 & 0.51 & 0.005 \\
\hline $\begin{array}{l}\text { Stomatal Conductance } \\
\left(\mathrm{mol} / \mathrm{m}^{2} / \mathrm{s}\right)\end{array}$ & 0.012 & 0.002 & 0.01 & 0.0011 & 0.001 & 0.0001 & 0.0006 & 0.0005 & 0.0001 & 0.0004 & 0.0002 & 0.0002 \\
\hline $\begin{array}{l}\text { Chlorophyll } a \\
\text { (mg/g fr. wt.) }\end{array}$ & 0.864 & 0.86 & 0.004 & 0.211 & 0.21 & 0.001 & 0.622 & 0.62 & 0.002 & 0.195 & 0.19 & 0.005 \\
\hline $\begin{array}{l}\text { Chlorophyll } b \\
\text { (mg/g fr. wt.) }\end{array}$ & 0.214 & 0.21 & 0.004 & 0.102 & 0.10 & 0.002 & 0.491 & 0.49 & 0.001 & 0.123 & 0.12 & 0.003 \\
\hline $\begin{array}{l}\text { Total Chlorophyll } \\
\text { (mg/g fr. wt.) }\end{array}$ & 1.884 & 1.87 & 0.014 & 0.483 & 0.48 & 0.003 & 2.172 & 2.17 & 0.002 & 0.533 & 0.53 & 0.003 \\
\hline $\begin{array}{l}\text { Carotenoid } \\
\text { (mg/g fr. wt.) }\end{array}$ & 0.163 & 0.16 & 0.003 & 0.053 & 0.05 & 0.003 & 0.221 & 0.22 & 0.001 & 0.032 & 0.03 & 0.002 \\
\hline $\begin{array}{l}\text { Total Soluble Protein } \\
\text { (mg/g fr. wt.) }\end{array}$ & 115.03 & 113.62 & 1.41 & 12.63 & 12.46 & 0.17 & 8.22 & 7.67 & 0.55 & 11.99 & 11.51 & 0.48 \\
\hline $\begin{array}{l}\text { Total Soluble Sugar } \\
\text { (mg/g dr. wt.) }\end{array}$ & 122.08 & 121.70 & 0.38 & 23.67 & 23.55 & 0.12 & 39.97 & 39.81 & 0.16 & 45.09 & 44.66 & 0.43 \\
\hline $\begin{array}{l}\text { Starch } \\
\text { (mg/g dr. wt.) }\end{array}$ & 145.66 & 144.79 & 0.87 & 41.00 & 40.74 & 0.26 & 43.28 & 43.04 & 0.24 & 50.74 & 50.30 & 0.44 \\
\hline
\end{tabular}

$\mathrm{Vp}=$ Phenotypic variance, $\mathrm{Vg}=$ Genetic variance, $\mathrm{Ve}=$ Environmental variance 
cent at Lachhiwala (Dehradun), 90.91 to 99.53 per cent at Lalkuwan (Haldwani), 83.33 to 99.91 per cent at Bithmera (Hisar) and 50.00 to 99.40 per cent at Mindo Mind Pandhori (Hoshiyarpur, Table 5). Collar diameter increment had maximum heritability coupled with high genetic gain at Lachhiwala (Dehradun) and Bithmera (Hisar) than the height increment whereas clones showed maximum heritability and less genetic gain for height increment at Lalkuwan (Haldwani) and more heritability at Pandhori Mindo Mind (Hoshiyarpur) than the collar diameter increment. Among the physiological parameters, photosynthetic and transpiration rates of clones also showed the maximum heritability coupled with higher genetic gain than the stomatal conductance at all sites. As far as biochemical parameters of the clones are concerned, maximum heritability coupled with higher genetic gain was shown by photosynthetic pigments followed by total soluble sugar, starch and total soluble protein contents at all sites.

\section{Discussion}

The better performance of clones belonging to the states of Uttaranchal (C019), Uttar Pradesh (C034 \& C192) and Haryana (C066) than the clones belonging to the state of Rajasthan; may be due to similar edapho-climatic conditions than other clones. Similarly the better clonal performance at Bithmera (Hisar) site than other sites; could also be ascribed to better edaphic conditions of the site (Table 2).

Variability estimates of different parameters, like growth, also indicated a wide range in the mean values, again depicting the presence of good amount of variation in clones at different sites. Collar diameter increment showed the high variance and coefficient of variability at genotypic level than the environmental level, which is also supported by higher heritability and genetic gain than the height increment at major sites. So it is clearly depicted that the expression of collar diameter is more controlled by the genetic make up of the clones. However, sites are also influencing the expression of growth parameters in some extent as the climatic and edaphic characteristics of the sites varied. Phenotypic and genotypic variances coupled with phenotypic and genotypic coefficient of variations for photosynthetic rate, transpiration and biochemical parameters of clones were almost similar which may be due to that expression of these parameters is mainly governed by genetic make up of the clones than the environment (sites). Stomatal conductance of the clones is more under the influence of the sites.

Heritability estimates in broad sense were more than the 75 percent for all the parameters at all the sites except this was low for height and collar diameter increment at Lachhiwala (Dehradun) and Pandhori Mindo Mind (Hoshiyarpur); which may be due to that differences in sites. However, high heritability coupled with same intensity of genetic gain was exhibited only for height and collar diameter increment at Bithmera (Hisar) and Pandhori Mindo Mind (Hoshiyarpur). This signifies that these parameters are under strong genetic control and contain good amount of heritable additive genetic components, which expressed their influence at these two sites. Studies conducted by DevaGIRI (1997) and GERA et al. (2001) lend a support to the present findings. High heritability accompanied by high genetic advance for several growth parameters have earlier been reported by DHILlon et al. (1995) in Dalbergia sis-

Table 4. - Estimates of coefficient of variability for different parameters at different sites.

\begin{tabular}{|c|c|c|c|c|c|c|c|c|c|c|c|c|}
\hline \multirow{3}{*}{ Parameters } & \multirow{2}{*}{\multicolumn{3}{|c|}{$\begin{array}{l}\text { Lachhiwala, Dehradun (UA) } \\
\text { Coefficient of Variability }\end{array}$}} & \multirow{2}{*}{\multicolumn{3}{|c|}{$\begin{array}{c}\text { Lalkuwan, Haldwani (UA) } \\
\text { Coefficient of Variability }\end{array}$}} & \multirow{2}{*}{\multicolumn{3}{|c|}{$\begin{array}{c}\text { Bithmera, Hisar (HR) } \\
\text { Coefficient of Variability }\end{array}$}} & \multirow{2}{*}{\multicolumn{3}{|c|}{$\begin{array}{l}\text { Pandhori Mindo Mind, } \\
\text { Hoshiyarpur (PB) } \\
\text { Coefficient of Variability }\end{array}$}} \\
\hline & & & & & & & & & & & & \\
\hline & PCV & $\mathrm{GCV}$ & $\mathrm{ECV}$ & PCV & $\mathrm{GCV}$ & $\mathrm{ECV}$ & PCV & GCV & $\mathrm{ECV}$ & $\mathrm{PCV}$ & $\mathrm{GCV}$ & $\mathrm{ECV}$ \\
\hline Height Increment (m) & 40.75 & 23.53 & 33.28 & 52.87 & 50.33 & 16.19 & 9.92 & 8.59 & 4.96 & 44.33 & 34.00 & 28.45 \\
\hline $\begin{array}{l}\text { Collar Diameter } \\
\text { Increment }(\mathrm{cm})\end{array}$ & 36.95 & 23.67 & 28.38 & 66.65 & 57.35 & 33.96 & 33.42 & 29.29 & 16.08 & 63.84 & 39.56 & 50.11 \\
\hline $\begin{array}{l}\text { Photosynthetic Rate } \\
\left(\mu \mathrm{mo} 1 / \mathrm{m}^{2} / \mathrm{s}\right)\end{array}$ & 13.10 & 13.04 & 1.27 & 11.91 & 11.86 & 1.09 & 12.30 & 12.09 & 2.26 & 10.34 & 10.30 & 0.80 \\
\hline $\begin{array}{l}\text { Transpiration Rate } \\
\left(\mathrm{mmol} / \mathrm{m}^{2} / \mathrm{s}\right)\end{array}$ & 19.69 & 19.59 & 1.93 & 17.75 & 17.70 & 1.36 & 19.04 & 18.94 & 1.92 & 14.80 & 14.72 & 1.46 \\
\hline $\begin{array}{l}\text { Stomatal Conductance } \\
\left(\mathrm{mol} / \mathrm{m}^{2} / \mathrm{s}\right)\end{array}$ & 36.51 & 14.91 & 33.33 & 12.76 & 12.16 & 3.85 & 8.75 & 7.98 & 3.57 & 8.33 & 5.89 & 5.89 \\
\hline $\begin{array}{l}\text { Chlorophyll } a \\
\text { (mg/g fr. wt.) }\end{array}$ & 29.60 & 29.53 & 2.01 & 12.72 & 12.69 & 0.88 & 28.47 & 28.43 & 1.61 & 16.42 & 16.20 & 2.63 \\
\hline $\begin{array}{l}\text { Chlorophyll } b \\
\text { (mg/g fr. wt.) }\end{array}$ & 20.65 & 20.46 & 2.82 & 12.52 & 12.40 & 1.75 & 34.01 & 33.98 & 1.53 & 20.63 & 20.38 & 3.22 \\
\hline $\begin{array}{l}\text { Total Chlorophyll } \\
\text { (mg/g fr. wt.) }\end{array}$ & 25.48 & 25.42 & 2.20 & 11.34 & 11.30 & 0.89 & 30.58 & 30.56 & 0.93 & 16.67 & 16.62 & 1.25 \\
\hline $\begin{array}{l}\text { Carotenoid } \\
\text { (mg/g fr. wt.) }\end{array}$ & 29.04 & 28.78 & 3.94 & 14.21 & 13.80 & 3.38 & 38.22 & 38.13 & 2.57 & 15.83 & 15.33 & 3.96 \\
\hline $\begin{array}{l}\text { Total Soluble Protein } \\
\text { (mg/g fr. wt.) }\end{array}$ & 26.33 & 26.17 & 2.91 & 12.39 & 12.31 & 1.44 & 9.48 & 9.16 & 2.45 & 12.31 & 12.06 & 2.46 \\
\hline $\begin{array}{l}\text { Total Soluble Sugar } \\
\text { (mg/g dr. wt.) }\end{array}$ & 21.49 & 21.46 & 1.20 & 10.95 & 10.93 & 0.78 & 13.35 & 13.33 & 0.84 & 14.61 & 14.54 & 1.43 \\
\hline $\begin{array}{l}\text { Starch } \\
\text { (mg/g dr. wt.) }\end{array}$ & 21.17 & 21.11 & 1.64 & 12.51 & 12.47 & 1.00 & 11.43 & 11.39 & 0.85 & 14.21 & 14.15 & 1.32 \\
\hline
\end{tabular}

$\mathrm{PCV}=$ Phenotypic coefficient of variation, GCV = Genotypic coefficient of variation, ECV = Environmental coefficient of variation. 
Table 5. - Estimates of heritability (broad sense) and genetic gain for different parameters at different sites.

\begin{tabular}{|c|c|c|c|c|c|c|c|c|c|c|c|c|}
\hline \multirow{3}{*}{ Parameters } & \multirow{2}{*}{\multicolumn{3}{|c|}{$\begin{array}{l}\text { Lachhiwala, Dehradun (UA) } \\
\text { Coefficient of Variability }\end{array}$}} & \multirow{2}{*}{\multicolumn{3}{|c|}{$\begin{array}{l}\text { Lalkuwan, Haldwani (UA) } \\
\text { Coefficient of Variability }\end{array}$}} & \multirow{2}{*}{\multicolumn{3}{|c|}{$\begin{array}{l}\text { Bithmera, Hisar (HR) } \\
\text { Coefficient of Variability }\end{array}$}} & \multirow{2}{*}{\multicolumn{3}{|c|}{$\begin{array}{l}\text { Pandhori Mindo Mind, } \\
\text { Hoshiyarpur (PB) } \\
\text { Coefficient of Variability }\end{array}$}} \\
\hline & & & & & & & & & & & & \\
\hline & $\mathrm{PCV}$ & GCV & $\mathrm{ECV}$ & PCV & GCV & $\mathrm{ECV}$ & PCV & GCV & $\mathrm{ECV}$ & PCV & GCV & $\mathrm{ECV}$ \\
\hline Height Increment (m) & 40.75 & 23.53 & 33.28 & 52.87 & 50.33 & 16.19 & 9.92 & 8.59 & 4.96 & 44.33 & 34.00 & 28.45 \\
\hline $\begin{array}{l}\text { Collar Diameter } \\
\text { Increment }(\mathrm{cm})\end{array}$ & 36.95 & 23.67 & 28.38 & 66.65 & 57.35 & 33.96 & 33.42 & 29.29 & 16.08 & 63.84 & 39.56 & 50.11 \\
\hline $\begin{array}{l}\text { Photosynthetic Rate } \\
\left(\mu \mathrm{mol} / \mathrm{m}^{2} / \mathrm{s}\right)\end{array}$ & 13.10 & 13.04 & 1.27 & 11.91 & 11.86 & 1.09 & 12.30 & 12.09 & 2.26 & 10.34 & 10.30 & 0.80 \\
\hline $\begin{array}{l}\text { Transpiration Rate } \\
\left(\mathrm{mmol} / \mathrm{m}^{2} / \mathrm{s}\right)\end{array}$ & 19.69 & 19.59 & 1.93 & 17.75 & 17.70 & 1.36 & 19.04 & 18.94 & 1.92 & 14.80 & 14.72 & 1.46 \\
\hline $\begin{array}{l}\text { Stomatal Conductance } \\
\left(\mathrm{mol} / \mathrm{m}^{2} / \mathrm{s}\right)\end{array}$ & 36.51 & 14.91 & 33.33 & 12.76 & 12.16 & 3.85 & 8.75 & 7.98 & 3.57 & 8.33 & 5.89 & 5.89 \\
\hline $\begin{array}{l}\text { Chlorophyll } a \\
\text { (mg/g fr. wt.) }\end{array}$ & 29.60 & 29.53 & 2.01 & 12.72 & 12.69 & 0.88 & 28.47 & 28.43 & 1.61 & 16.42 & 16.20 & 2.63 \\
\hline $\begin{array}{l}\text { Chlorophyll } b \\
\text { (mg/g fr. wt.) }\end{array}$ & 20.65 & 20.46 & 2.82 & 12.52 & 12.40 & 1.75 & 34.01 & 33.98 & 1.53 & 20.63 & 20.38 & 3.22 \\
\hline $\begin{array}{l}\text { Total Chlorophyll } \\
\text { (mg/g fr. wt.) }\end{array}$ & 25.48 & 25.42 & 2.20 & 11.34 & 11.30 & 0.89 & 30.58 & 30.56 & 0.93 & 16.67 & 16.62 & 1.25 \\
\hline $\begin{array}{l}\text { Carotenoid } \\
\text { (mg/g fr. wt.) }\end{array}$ & 29.04 & 28.78 & 3.94 & 14.21 & 13.80 & 3.38 & 38.22 & 38.13 & 2.57 & 15.83 & 15.33 & 3.96 \\
\hline $\begin{array}{l}\text { Total Soluble Protein } \\
\text { (mg/g fr. wt.) }\end{array}$ & 26.33 & 26.17 & 2.91 & 12.39 & 12.31 & 1.44 & 9.48 & 9.16 & 2.45 & 12.31 & 12.06 & 2.46 \\
\hline $\begin{array}{l}\text { Total Soluble Sugar } \\
\text { (mg/g dr. wt.) }\end{array}$ & 21.49 & 21.46 & 1.20 & 10.95 & 10.93 & 0.78 & 13.35 & 13.33 & 0.84 & 14.61 & 14.54 & 1.43 \\
\hline $\begin{array}{l}\text { Starch } \\
\text { (mg/g dr. wt.) }\end{array}$ & 21.17 & 21.11 & 1.64 & 12.51 & 12.47 & 1.00 & 11.43 & 11.39 & 0.85 & 14.21 & 14.15 & 1.32 \\
\hline
\end{tabular}

soo; GERA et al. (2001) in Tectona grandis and DHILLON et al. (2003) in Azadirachta indica. JoHnson et al. (1955) suggest that heritability estimates in conjunction with genetic advance are usually more helpful in predicting its resultant effect for selecting the best genotypes. High heritability (broad sense) may be due to non-additive gene action so it shall be reliable only if accompanied by high genetic gain. The findings of the present investigation are in congruous with that of RAMCHANDRA (1996) and DEVAGIRI (1997).

On the basis of variability estimates and genetic components it can be depicted that collar diameter, photosynthetic rate, transpiration rate and biochemical parameters of the clones are under the strong genetic control and could be considered reliable for selection for further improvement of this species. However, height increment and stomatal conductance was more under the control of environment and non-additive in nature, therefore, not reliable as a selection criteria.

\section{References}

Burton, G. W. (1952): Quantitative inheritance in grasses. Proceeding of $6^{\text {th }}$ International Grassland Conference 1: 277-283.

Burton, G. W. and E. W. Devane (1953): Estimating heritability in tall Festuca arundinacea from replicated clonal material. Agronomic Journal 4: 78-81.

DEvagiRI, G. M. (1997): Evaluation of seed source variation in seed and seedling traits in Dalbergia sissoo Roxb. Ph.D. Thesis, Forest Research Institute (Deemed University), Dehradun, India.

Dhillon, R. S., S. S. Bisla, S. K. Dhanda and V. P. Singh (1995): Genetic variation and heritability of some growth traits in shisham (Dalbergia sissoo Roxb.). Annals of Biology 11: 107-110.
Dhillon, R. S., S. S. Bisla, S. ARYA and M. S. HoodA (2003): Genetic variation, heritability and correlations for growth parameters in Azadirachta indica A. Juss. Annals of Forestry 11: 215-221.

Dubois, M., K. A. Gillies, J. K. Hamilton, P. A. Rebers and F. SMiтh (1956): Colorimetric method for determination of sugars and related substances. Analytical Chemistry 28: 350-356.

Gera, M., N. Gera and S. Sharma (2001): Estimation of variability in growth characters of forty clones of Tectona grandis. Indian Forester 127: 639-643.

Holm, G. (1954): Chlorophyll mutations in barley. Acta. Agri. Scand. 4: 457-461.

Johnson, H. W., H. F. Robinson and R. F. Comstock (1955): Estimates of genetic and environmental variability in soyabean. Agronomic Journal 47: 314-318.

Lowry, O. H., N. J. Rosebrough, A. L. Farr and R. J. RANDALL (1951): Protein measurements with the folin phenol reagent. Journal of Biological Chemistry 193: 265-275.

RAMCHANDRA, N. G. (1996): Provenance variation in seed and seedling parameters in Acacia catechu Will. Ph. D. Thesis, Forest Research Institute (Deemed University), Dehradun, India.

REHMAN, S. and A. Hussain (1986): Growth and heritability estimates among six years old three geographical sources of shisham (Dalbergia sissoo Roxb.) in Pakistan. Pakistan Journal of Forestry 36 (2): 67-72.

VIDAKOvIC, M. and K. M. SIDDIQUI (1968): Heritability of height and diameter growth in shisham (Dalbergia sissoo) using one parent progeny test. Pakistan Journal Forestry 18: 75-94.

VIDAKOvic, M. and J. AHSAN (1970): The improvement of stem form in shisham (Dalbergia sissoo Roxb.). Pakistan Journal of Forestry 20: 115-119. 